- $\underbrace{\text { Agriculture Update_ }}_{\text {ISSN-097-6847 }}$

\title{
Research Article: Knowledge and adoption of recommended package of practices by banana growers
}

K.S. NAIK AND P.R. DESHMUKH

Article Chronicle: Received :

13.08.2013;

Revised :

01.01.2016;

Accepted :

15.01.2016

KEY WoRDS :

Knowledge,

Adoption

Author for correspondence :

\section{K. S. NAIK}

Department of Extension Education,Vasantrao Naik Marathwada Krishi

Vidyapeeth, PARBHANI

(M.S.) INDIA

Email: ksnaik464@

gmail.com

See end of the article for

authors' affiliations
SUMMARY : The study was conducted in randomly selected districts of Marathwada region viz., Nanded and Hingoli of Maharashtra state. Results of study revealed that majority of the respondents belong to medium farming experience, educated upto secondary school level, had nuclear type of family, semi-medium size of land holding and marginal land holding about area under banana. Majority of them had annual income of Rs. 1,10,751 to 9,77,750/-. Majority of the banana growers used well as a source of irrigation. Majority of the banana growers were having medium extension contact, social participation, sources of information and market orientation. Majority of the respondents $(51.67 \%)$ belong to the medium level of knowledge and (48.83\%) were falling under medium level of adoption.

How to cite this article : Naik, K.S. and Deshmukh, P.R. (2016). Knowledge and adoption of recommended package of practices by banana growers. Agric. Update, 11(1): 41-44. 